\title{
Winter foraging by a top predator, the grey seal Halichoerus grypus, in relation to the distribution of prey
}

\author{
V. Harvey ${ }^{1}$, M. O. Hammill ${ }^{1, *}$, D. P. Swain ${ }^{2}$, G. A. Breed ${ }^{3}$, C. Lydersen ${ }^{4}$, K. M. Kovacs ${ }^{4}$ \\ ${ }^{1}$ Maurice Lamontagne Institute, Mont-Joli, Quebec G5H 3Z4, Canada \\ ${ }^{2}$ Gulf Fisheries Centre, Moncton, New Brunswick E1C 9B6, Canada \\ ${ }^{3}$ UC Santa Cruz, Long Marine Lab, Santa Cruz, California 95060, USA \\ ${ }^{4}$ Norwegian Polar Institute, Tromsø 9296, Norway
}

\begin{abstract}
Identifying foraging areas of individuals and correlating them with potential food resources allows for a better understanding of predator-prey relationships. Herein, we examine whether grey seal movements were associated with overwintering concentrations of several commercial fish species in the Cabot Strait, Atlantic Canada, using data from satellite transmitters deployed on grey seals (between 1993 and 2005) and winter bottom-trawl survey data (1994 to 1997). The distribution of searching effort by male grey seals varied throughout the winter. In early winter, males concentrated their movements around St. Paul's Island. In late winter, they were found to the southeast of this area, where females also occurred. The fish community differed between apparent foraging and non-foraging areas. Densities of small plaice, hake and redfish, large herring and cod of all sizes were relatively high in the male grey seal foraging zones; female foraging zones were characterized by higher densities of small plaice and redfish and large cod. Areas where grey seal foraging was not concentrated were characterized by high densities of medium and large redfish as well as large turbot and witch flounder. Diet samples are needed to determine whether grey seals are feeding on the fish groups that distinguish foraging from nonforaging areas or alternatively on other prey that occur in the same areas.
\end{abstract}

KEY WORDS: Marine predator · Foraging areas $\cdot$ Cod $\cdot$ Spatial overlap $\cdot$ First-passage time · Groundfish · Gulf of St. Lawrence

Resale or republication not permitted without written consent of the publisher

\section{INTRODUCTION}

Relationships between predators and their prey are complex and include both direct and indirect effects operating at different trophic levels. Several studies have explored the impacts of marine mammals and other predators on their prey using ecosystem models and have suggested that upper level consumers contribute to maintaining structure in marine ecosystems (Yodzis 1998, Morissette et al. 2006, Savenkoff et al. 2007).

Northwest Atlantic ecosystems have undergone significant changes in recent decades (e.g. Savenkoff et al. 2007). In the southern Gulf of St. Lawrence (Gulf), the biomass of large demersal fishes, most notably Atlantic cod Gadus morhua, collapsed in the late 1980s and early 1990s due to overfishing. Fishing effort directed at cod, the main target of demersal fishing in the southern Gulf, was sharply reduced in 1993 and has remained low since that time. Despite nearly 20 yr with very low fishing mortality, demersal fish populations in the southern Gulf have failed to recover, primarily due to elevated natural mortality of adult fish (e.g. Swain \& Chouinard 2008, Swain et al. 2009). For example, estimates of fishing and natural mortality of cod in 2008 (Swain et al. 2009) corre- 
spond to annual losses of $<5 \%$ of adult cod to fishing and $\sim 45 \%$ to natural mortality. It has been suggested that predation by an increasing grey seal population (Thomas et al. 2008) may be an important factor in the elevated natural mortality of adult cod (Chouinard et al. 2005, Benoît \& Swain 2008, Swain et al. 2009). However, diet studies from the southern Gulf have not supported the hypothesis that seals are consuming large numbers of large cod (e.g. Hammill et al. 2007). But these studies, which are based on prey hard parts (in particular otoliths or ear bones) found in the digestive tracts of seals, may underestimate the consumption of large fish if their heads are not consumed (Hauser et al. 2008, Phillips \& Harvey 2009) or if sampling has not occurred where grey seals and large fish overlap (Benoit et al. 2011).

The overwintering period, when southern Gulf cod occur in dense aggregations at consistent locations (see 'Results'), is a period when cod may be an attractive prey resource to grey seals. However, sampling of seals for diet studies at this time of year is logistically challenging. In theory, the availability and distribution of resources is expected to affect the distribution of animals as well as their space-use strategy (Johnson 1980, Manly et al. 2002), and effective predators should concentrate effort in areas with the highest probability of capturing prey (Fauchald \& Tveraa 2003). Thus, identifying areas of intensive use by grey seals and relating them to the distribution of potential prey may provide clues to seal diets in these offshore, difficult to sample areas. In the present study, we describe grey seal movements in the vicinity of the overwintering grounds of cod and other commercially important fishes. We compare the fish community composition between areas where seals concentrate their time (presumably foraging) and areas where seals do not show evidence of foraging. We suggest that fish species (and size classes) characteristic of the areas used by foraging seals represent potential prey of these seals.

\section{MATERIALS AND METHODS}

\section{Study area}

The present study encompassed portions of the Gulf, Cabot Strait and Scot- ian Shelf of eastern Canada (Fig. 1). This area is dominated by the deep Laurentian Channel $(>300 \mathrm{~m})$, with a shallow shelf $(<200 \mathrm{~m})$ to the southwest and a number of shallow banks to the northeast. The southern Gulf is largely ice-covered in winter. Most commercial fish species leave the southern Gulf in late fall, overwintering in the deep waters of the Laurentian Channel or along its southern slope (e.g. Swain et al. 1998). Northwest Atlantic grey seals are widely distributed throughout this area and over the Scotian shelf in summer. In autumn, grey seals leave the northern Gulf and move into the southern Gulf or onto the Scotian Shelf. Breeding aggregations form on small islands and on the pack-ice in the southern Gulf, along coastal Nova Scotia and on Sable Island from December to February (Lavigueur \& Hammill 1993).

\section{Fish distribution}

Bottom trawl surveys were conducted in the Cabot Strait area in January of 1994 to 1997 by the RV 'Alfred Needler' (1994 to 1995) or 'Wilfred Templeman' (1996 to 1997) (Chouinard \& Hurlbut 2011). The 1994 survey followed a stratified random design. Stations for the 1995 to 1997 surveys were allocated following a regular $12 \times 12$ nautical mile grid (with an

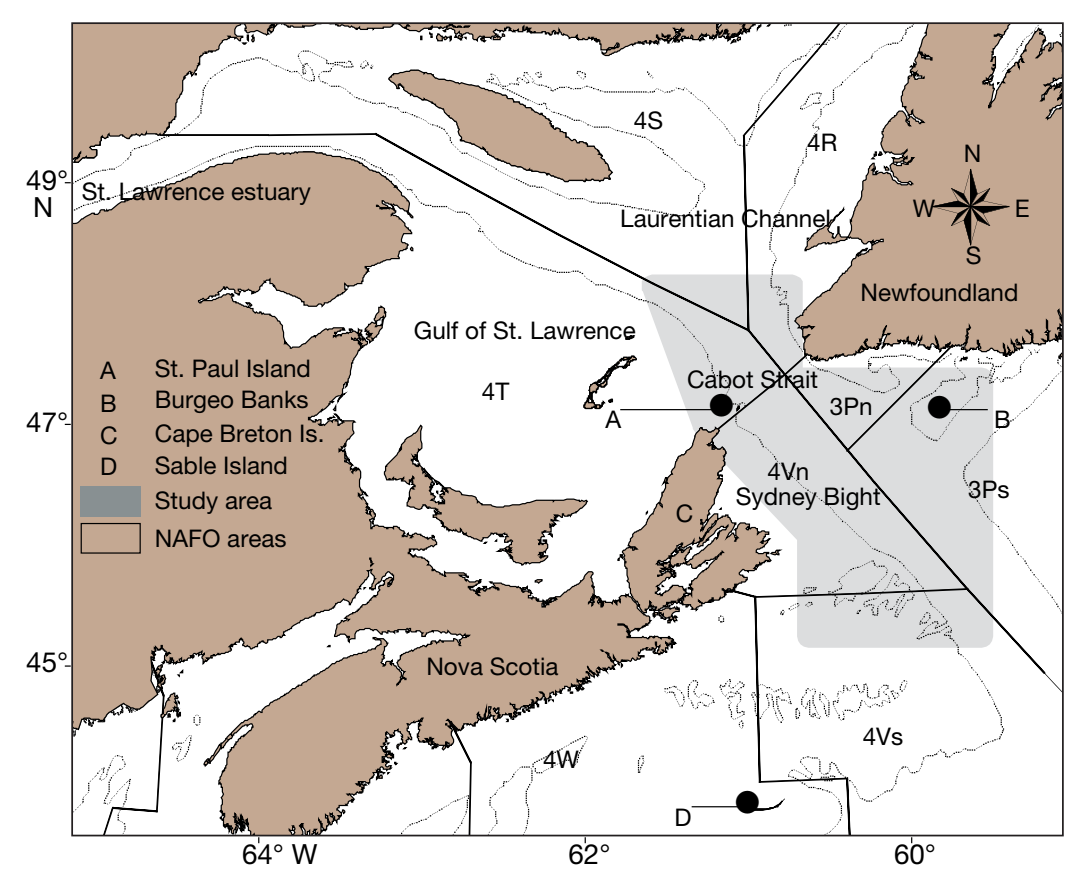

Fig. 1. Study area (grey shading) and the surrounding region. Solid lines: Northwest Atlantic Fishery Organization (NAFO) divisions (e.g. 4T) and subdivisions (e.g. 4Vn). Dotted lines: $200 \mathrm{~m}$ depth contour 
additional station located midway between the regular grid points in areas along the $200 \mathrm{~m}$ contour where cod concentrations were expected). The 1994 survey was restricted to the south side of the Laurentian Channel (in NAFO Divisions $4 \mathrm{~T}$ and $4 \mathrm{Vn}$ ), whereas the 1995 to 1997 surveys also covered the north side of the channel (in Divisions 4R and 3Pn). Surveys conducted by the RV 'Alfred Needler' used a Western IIA bottom trawl, whereas those conducted by the RV 'Wilfred Templeman' used a Campelen 1800 trawl. Target fishing procedures were a $30 \mathrm{~min}$ tow at 3.5 knots by the 'Alfred Needler' or a $15 \mathrm{~min}$ tow at 3 knots by the 'Wilfred Templeman'. All catches were adjusted to a standard tow of $1.75 \mathrm{n}$ miles for the 'Alfred Needler' surveys or $0.75 \mathrm{n}$ miles for the 'Wilfred Templeman'.

Seven common, commercially important fish species were selected for analysis, including species frequently (e.g. herring and cod) or rarely (e.g. witch flounder and turbot) reported in grey seal diets. For each fish species, survey catches were divided into 2 or 3 size classes (Table 1), for a total of 16 fish groups. To adjust for the size-dependent differences in fishing efficiency between the Western IIA and Campelen trawls, catch rates for a particular species and size class were adjusted to produce the same average value in each year in a subset of the survey area sampled in all years, as follows:

$$
x_{i j}^{\prime}=x_{i j} \frac{\bar{X}}{\bar{X}_{\cdot j}}
$$

where $x_{i j}$ is the catch of the species and size class in tow $i$ in year $j, \bar{X}_{\cdot j}$ is the average catch in year $j$ in the area sampled in all years, and $\bar{X}$. is the average of the 4 annual averages.

We combined data from all 4 years to estimate the average distribution of each of the 16 fish groups in January 1994 to 1997 . These average fish distributions were then related to the foraging distributions of grey seals throughout the study period (winter, 1993 to 2005). This assumes that the average distribution in January 1994 to 1997 is representative of fish distribution throughout the winter over the whole 1993 to 2005 period (this assumption is addressed in the 'Discussion'). Fish densities were estimated at each point on a $10 \times 10 \mathrm{~km}$ grid, using the Geostatistical Analyst extension of ArcGIS v9.2 (Environmental System Research Institute). Estimates were made by ordinary kriging using an omni-directional, spherical semivariogram model, a standard approach for mapping fish abundance data from trawl surveys (e.g. Rivoirard et al. 2000). Catch rates were averaged when $>1$ value was available at the same location. The boundary of the study area was defined as a polygon that extended $10 \mathrm{~km}$ beyond the survey stations.
Table 1. Fish species and size classes used in the present study. Total catch of each fish group in the January 1994 to 1997 surveys was adjusted for differences in fishing efficiency between years (see Eq. 1)

\begin{tabular}{|lccccccc|}
\hline \multirow{2}{*}{ Fish } & \multirow{2}{*}{$\begin{array}{c}\text { Length } \\
(\mathrm{cm})\end{array}$} & Size & \multicolumn{5}{c|}{ Adjusted catch } \\
\cline { 5 - 8 } & class & 1994 & 1995 & 1996 & 1997 & Total \\
\hline American plaice & $<30$ & Small & 3236 & 6037 & 3707 & 2746 & 15725 \\
Hippoglossoides & $>30$ & Large & 2023 & 2860 & 1889 & 1175 & 7945 \\
platessoides & & & & & & & \\
White hake & $<35$ & Small & 1437 & 2213 & 1401 & 1244 & 6292 \\
Urophycis tenuis & $>35$ & Large & 587 & 842 & 675 & 446 & 2548 \\
Turbot & $<35$ & Small & 93 & 270 & 267 & 94 & 723 \\
Reihhardtius & $>35$ & Large & 693 & 1613 & 2385 & 1076 & 5765 \\
hippoglossides & & & & & & & \\
Witch flounder & $<30$ & Small & 1195 & 3196 & 2920 & 1392 & 8701 \\
Glyptocephalus & $>30$ & Large & 1001 & 2221 & 2245 & 1171 & 6637 \\
cynoglossus & & & & & & & \\
Herring & $<30$ & Small & 881 & 1571 & 1911 & 7986 & 12347 \\
Clupea harengus & $>30$ & Large & 2339 & 7047 & 2939 & 4792 & 17116 \\
Redfish & $<20$ & Small & 1978 & 3261 & 4444 & 4380 & 14062 \\
Sebastes sp. & $20-30$ & Medium & 730 & 3306 & 10325 & 2551 & 16910 \\
& $>30$ & Large & 1200 & 4167 & 11595 & 3426 & 20387 \\
Cod & $<25$ & Small & 807 & 1271 & 2150 & 599 & 4826 \\
Gadus morhua & $25-35$ & Medium & 3303 & 4758 & 4599 & 6314 & 18973 \\
& $>35$ & Large & 12226 & 8121 & 7120 & 8985 & 36451 \\
\hline
\end{tabular}

\section{Grey seals}

A total of 192 grey seals were captured at Sable Island (134), the St. Lawrence Estuary (3) and the Gulf of St Lawrence (55) between 1993 and 2005 (Fig. 1) (Breed et al. 2006, Harvey et al. 2008). An incisor tooth was extracted for age determination in the Gulf (Bernt et al. 1996), while animals from Sable Island were marked as pups, so their ages were known at subsequent capture (Beck et al. 2007). Animals were classified as juveniles $(<6$ yr old) or adults ( $\geq 6$ yr old) (Harvey et al. 2008). A satellite time-depth recorder was glued to the upper neck or head of each seal using a quicksetting epoxy (Breed et al. 2006, Harvey et al. 2008). All animal handling procedures followed the guidelines of the Canadian Council on Animal Care (1993). 


\section{Modelling path trajectories}

Seal movements were described using a firstdifference correlated random walk model with a 480 min time-step (3 locations per day) (Breed et al. 2009). The path of each individual was analysed to identify seals that occurred within the study area during winter, which was identified as the period from 12 December, the mean date of departure for the autumn migration for the seals included in our analyses, until 30 April. The breeding season (1 to 21 January) was excluded from the analyses.

\section{Identification of foraging zones}

We calculated the time spent by seals along different parts of their tracks using first-passage time (FPT) analyses (Fauchald \& Tveraa 2003). FPT is defined as the time required for an animal to cross a circle of a given radius. This analysis allowed us to identify where individuals spent their time along a track and at which scale they adopted an area restricted search (ARS). We assumed that the presence of an ARS represented foraging behaviour (e.g. Weimerskirch et al. 2007). For each track, we calculated the FPT for points interpolated at $2 \mathrm{~km}$ intervals along the path for radii ranging from 4 to $100 \mathrm{~km}$ (Freitas et al. 2008). The variance of the log-transformed FPTs was calculated and plotted to identify the radius at which the maximum variance occurred (Fauchald \& Tveraa 2003). The FPT at each point along the track, calculated at the radius with maximum variance in FPT for each individual, was then used to compare the time spent by the animal along the different parts of its track. We performed the FPT analyses only on tracks with $>15$ locations (Pinaud 2008). Analyses were completed using custom software (A. Mosnier, University of Quebec at Rimouski). The presence of multiple spatially distinct ARS zones along the path was determined following the method developed by Lemieux-Lefebvre (2009).

The effects of sex, season, age class and region within the study area on ARS size were determined using general linear mixed models fitted by maximum-likelihood parameter estimation. 'Individual' was considered as a repeated factor in the model. All possible models with 2-way interactions were tested and compared to the mean model: $y=\mu+\varepsilon$. Variables included in each model were entered simultaneously. The ARS size was $\log _{\mathrm{e}}$-transformed to meet the assumptions of parametric analyses. Model selection based on changes in Akaike's information criterion $(\triangle \mathrm{AIC})$ and AIC weights was used to select the most parsimonious model. Models with $\triangle$ AIC $\leq 2$ were considered to be equivalent. When models were equivalent, the model with the fewest parameters was retained as the best one (Burnham \& Anderson 2002).

\section{Spatial overlap between seals and fish}

We examined the overlap between seals and potential fish prey in 2 ways. First, we compared fish densities between areas where seals foraged with fish densities and areas where seals did not forage. We then examined differences in community composition between foraging and non-foraging zones using a nonmetric, multi-dimensional scaling (MDS) approach, in which differences between zones were tested by analysis of similarity (ANOSIM). In the first approach, fish densities were compared between observed ARS zones and randomly located circles of similar size. For each identified ARS, we generated 40 circles of the same radius at random locations within the study area. This number was selected because the mean density for each fish group converged to the average in the study area with 40 samples. Random circles were retained if $>50 \%$ of their area was within the study area (Harvey et al. 2008). Three very large ARS zones (radius $\geq 80 \mathrm{~km}$ ) were omitted because they occupied vast areas and the seal track occupied only a very small zone within each circle. A total of 2000 random circles were generated. Only 62 had $>50 \%$ overlap with the study area but $<1 \%$ overlap with the foraging circles. These were classified as nonforaging circles. Densities of each fish group were compared between male foraging zones $(n=26)$, female foraging zones $(\mathrm{n}=19)$ and these non-foraging zones $(n=62)$. To estimate mean density in each zone, each fish group was split into 10 density classes (based on percentiles of the density distribution for that group). The average density of the group within each circle was calculated as the weighted average of the median densities of each density class, with the weighting based on the proportion of the circle area attributed to each density class.

In the second approach, we implemented the randomisation analysis described by Clarke \& Green (1988) to calculate the significance of differences among fish communities in female foraging, male foraging and non-foraging areas (ARS zones). A BrayCurtis similarity matrix was computed to compare the 107 zones. Based on this similarity matrix, an ordination of the zones was produced using non- 
metric MDS. Differences in the fish community composition between foraging and non-foraging zones were tested by ANOSIM (Clarke \& Green 1988). This approach uses randomisation tests based on permutations of the similarity matrix. The test statistic $R$ was calculated as follows:

$$
R=\frac{\overline{\mathrm{r}_{B}}-\overline{\mathrm{r}_{W}}}{\frac{1}{2} M}
$$

where $\overline{r_{W}}$ is the average of all rank similarities among zones of the same type, i.e. female foraging, male foraging or non-foraging areas, $\overline{r_{B}}$ is the average rank similarity among zones of different types, $M=$ $n(n-1) / 2$, and $n$ is the total number of zones. Zones were randomly re-assigned to types, and $R$ was calculated for each of 999 random permutations. The significance level for the difference between zone types was given by $(N+1) / 1000$, where $N$ is the number of random permutations yielding an $R$ greater than or equal to that of the observed data. Computations were made using the software programme PRIMER (Clarke \& Gorley 2001).

\section{RESULTS}

\section{Fish distribution and abundance}

Atlantic cod was the most abundant fish species in the January survey catches, accounting for $19 \%$ of the total catch by number and $38 \%$ of the catch by weight. Large aggregations of cod belonging to the northern Gulf population occurred in deep water on the north side of the channel. However, the greatest concentrations of cod, belonging to the southern Gulf population (Swain et al. 2001), occurred along the southern slope of the Laurentian Channel near the $200 \mathrm{~m}$ depth contour (Fig. 2). In this area, a dense concentration of all size classes of cod, just north of Cape Breton in the vicinity of St. Paul Island, was evident in all years (Fig. 2) (see Fig. A1 in the Appendix). Additional concentrations of large cod occurred further to the southeast near the $200 \mathrm{~m}$ contour. The location and importance of these additional aggregations varied from year to year. The very dense aggregation of large cod at the southeastern edge of the study area is due to a single large catch in 1994 (see Fig. A1). Smaller cod occupied shallower depths than larger cod.

Redfish were the second most common species caught, accounting for $15 \%$ of the total catch by number and $18 \%$ of the catch by weight. Redfish were most abundant on the north side of the Laurentian Channel, with the larger fish of this species found in deeper water (Fig. 2). Some small redfish also occurred along the southern slope of the Laurentian Channel, mostly around St. Paul Island and at the southeastern end of the study area. Herring, the third most common species ( $9 \%$ by number, $6 \%$ by weight), was most abundant on the shelf, south of the Laurentian Channel, again with smaller fish found in shallower water (Fig. 2). The highest concentrations of herring occurred between Cape Breton and St. Paul Island, along the $200 \mathrm{~m}$ contour to the southeast of this area and near the southeastern limit of the study area.

The remaining species were, for the most part, restricted to waters deeper than $200 \mathrm{~m}$ in the Laurentian Channel (Fig. 2). White hake occurred mainly along the south slope of the Laurentian Channel, just beyond the $200 \mathrm{~m}$ contour. Plaice were most abundant in the northern part of the study area, particularly in the deep waters of the Laurentian Channel. Witch flounder and turbot were distributed predominantly in deep waters $(>400 \mathrm{~m})$ in the central region of the Laurentian Channel.

Considering all 16 fish groups, fish were concentrated in 3 areas. One concentration, consisting of high densities of cod and herring (all size classes), occurred in the area from Cape Breton to St. Paul Island. A second concentration consisting of large cod and large herring as well as American plaice, white hake, small redfish and large witch flounder occurred along the southern slope of the Laurentian Channel at the southeastern limit of the study area. A third concentration consisting of large cod and medium and large redfish occurred in the Burgeo Bank area.

\section{Grey seal telemetry}

A total of 172 grey seals were tagged between 1993 and 2005; 53 animals were tagged during the period when the fish surveys were conducted. Animals were tracked for a mean duration of $164 \pm 7 \mathrm{~d}$ (range $=19$ to $359 \mathrm{~d}$ ) with a total of $28428 \mathrm{~d}$ of tracking. Of these seals, 35 (14 from Sable Island; 21 from Gulf of St Lawrence; 15 males, 20 females) travelled within the study area during the winter period at least once. A total of 970 seal days were recorded in the study area, including 2908 locations. Individual seals stayed in the study area for an average of $10.9 \pm 1.4 \mathrm{~d}$ (range $=0.3$ to $61 \mathrm{~d}$ ). Seven seals travelled to the study area both before and after breeding. 


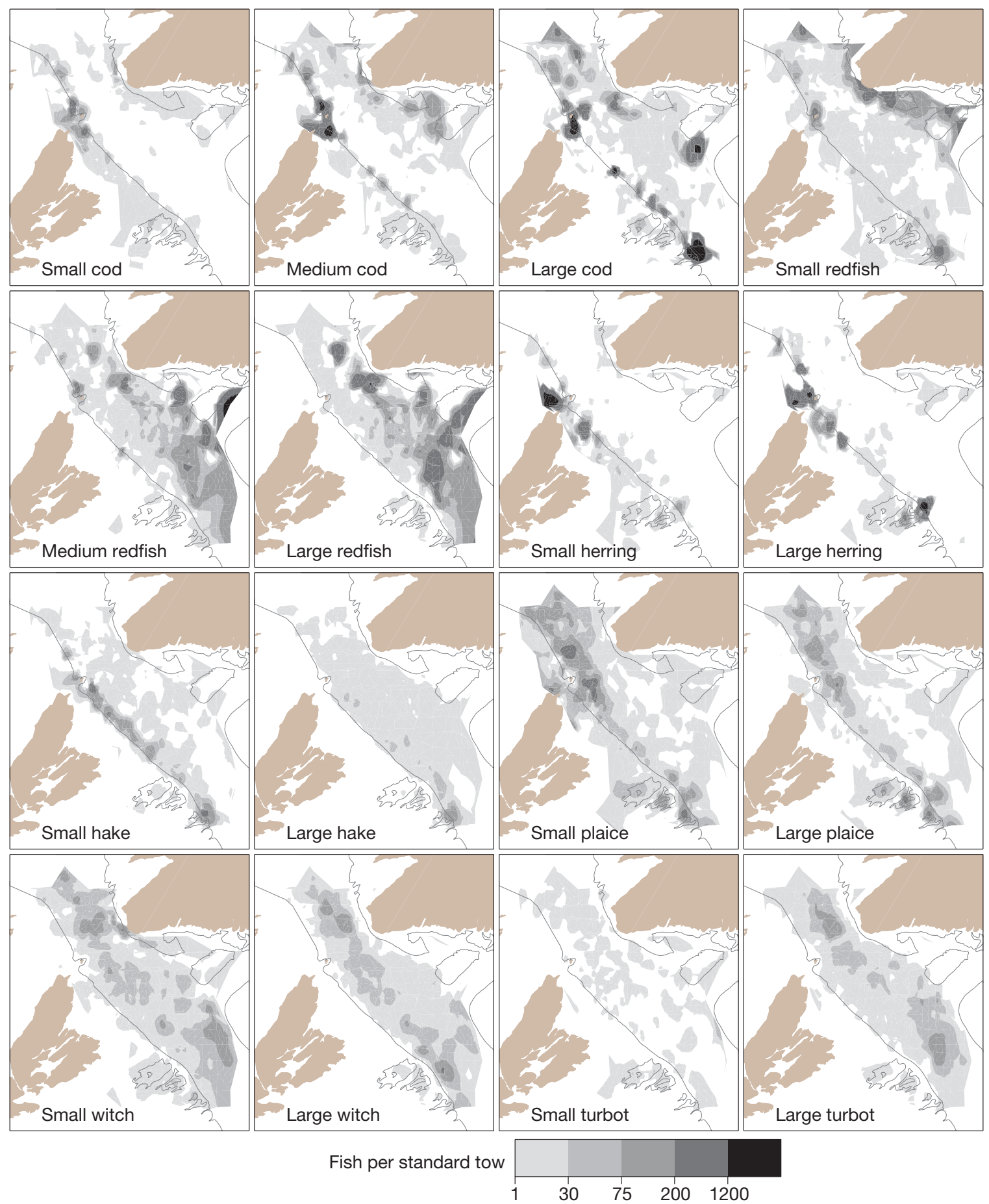

Fig. 2. Fish distribution by species and size class in the Cabot Strait area in January 1994 to 1997 derived from bottom-trawl surveys. Shaded contours were drawn using Delaunay triangles. See Table 1 for full species names and size class definitions

\section{FPT analyses}

FPT analysis was applied to 56 segments or paths from the 35 seals that frequented the study area in the winter. The paths of these seals were largely restricted to the southern portion of the study area in the waters off Cape Breton.

A peak in variance was detected in 52 paths $(95 \%)$, and a total of 158 ARS zones were identified. Excluding the 3 ARS with a diameter 
$>80 \mathrm{~km}, 45$ of the ARS (16 adult females, 3 juvenile females, 7 adult males, 19 juvenile males), created by 20 individuals, were within the study area $(26$ before 1998, 19 after 1998; 3 females, 2 males tagged at Sable Island; 6 females, 9 males tagged within the Gulf) (Fig. 3). Five individuals concentrated their searching effort at 2 different spatial scales and were then considered as different individuals at each of the 2 scales in our analyses. The radii of the ARS varied from 8 to $60 \mathrm{~km}$, with a mean of $19.5 \pm 1.5 \mathrm{~km}$. Only males had ARS within the study area before the breeding period, whereas both males and females had ARS within the study area after the breeding period. There was no difference in the time animals spent before and after breeding within the study area $\left(F_{1,10}=-1.00 ; \mathrm{p}=\right.$ $0.34)$, nor were there any sex $\left(F_{1,24}=-1.27 ; \mathrm{p}=\right.$ $0.22)$, age class $\left(F_{1,24}=0.20 ; \mathrm{p}=0.84\right)$ or capture site $\left(F_{1,24}=0.14 ; \mathrm{p}=0.89\right)$ effects on the size of ARS. Overall, seals stayed for $15.3 \pm 2.6 \mathrm{~d}$ within a given ARS. Age class $\left(F_{1,46}=-0.84 ; \mathrm{p}=0.41\right)$ and capture site $\left(F_{1,46}=-0.04 ; \mathrm{p}=0.96\right)$ did not influence time spent within the ARS, but males spent more time $(19.1 \pm 3.8 \mathrm{~d})$ within their ARS than females $(10.1 \pm 2.97 \mathrm{~d})\left(F_{1,46}=-1.79 ; \mathrm{p}=0.08\right)$.

The ARSs within the study area were concentrated near St. Paul Island and in the southern part of the study area on the Scotian Shelf. The former area was used at the beginning of the winter (mean date: 14 December to 6 January), whereas the latter area was used by seals later in the winter (23 January to 15 February). Males and females concentrated their searching efforts in different parts of the study area. The ARSs of males from the Gulf $(\mathrm{n}=7)$ and one male from Sable Island were concentrated around St. Paul Island (11 ARS) (Fig. 3c). Males (Gulf: 5; Sable: 2) also exhibited foraging effort offshore, north of Cape Breton (14 ARS). Males that foraged around St. Paul Island also hauled out on the island between trips at sea. Nine ARS associated with males tagged at Sable Island were within the southern part of the study area. These animals made return trips to Sable Island. Females ( $\mathrm{n}=19$, all from Sable Island) concentrated their searching effort in the southern portion of the study area, from which they also made return trips to Sable Island (Fig. 3c). A total of 12 of 18 animals observed within the study area in winter before 2000 (Gulf: 15; Sable: 3) had an ARS around St. Paul Island, while after 2000, only 4 out of 17 (Gulf: 6; Sable: 11) animals that travelled within the study area during the winter period had an ARS in this area.
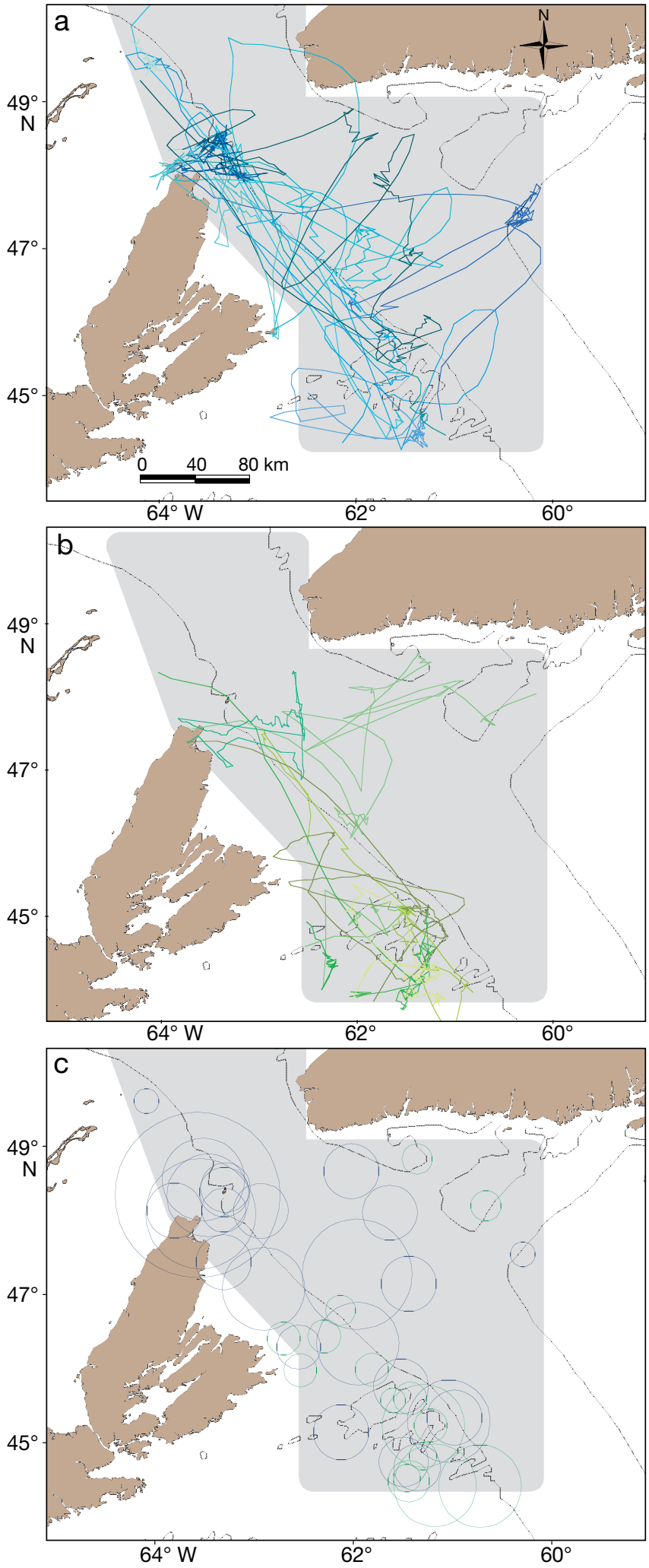

Fig. 3. Halichoerus grypus. Paths of (a) male ( $\mathrm{n}=26$; blue) and (b) female ( $\mathrm{n}=19$; green) satellite tag-equipped grey seals in the Cabot Strait during the winter period. (c) Areas of restricted search for both sexes 
Fish community differences between foraging and non-foraging zones

In the male foraging zones, densities of large herring, small size groups of plaice, hake and redfish and all sizes of cod were high compared to the non-foraging zones (Fig. 4). In the female foraging zones, the estimated densities of all fish species examined were generally low, though the abundance of small plaice and redfish was higher in these zones than in the non-foraging zones. In the non-foraging zones, large size classes of witch flounder, turbot and redfish were considerably more abundant than in the male or female foraging zones.
The MDS ordination indicated that the fish communities within non-foraging zones were similar to each other but were distinct from those of foraging zones (Fig. 5). The foraging zones were more widely dispersed in the ordination, indicating a more variable fish community. Based on the randomisation test, highly significant $(p<0.01)$ differences in fish community composition occurred among the male foraging, female foraging and non-foraging zones. Differences were also significant in all pairwise comparisons between zone types, though the differences between the 2 foraging zone types (male or female) and non-foraging zones were much more significant $(p<0.01)$ than the difference between male and female foraging zones $(\mathrm{p}<0.05)$.
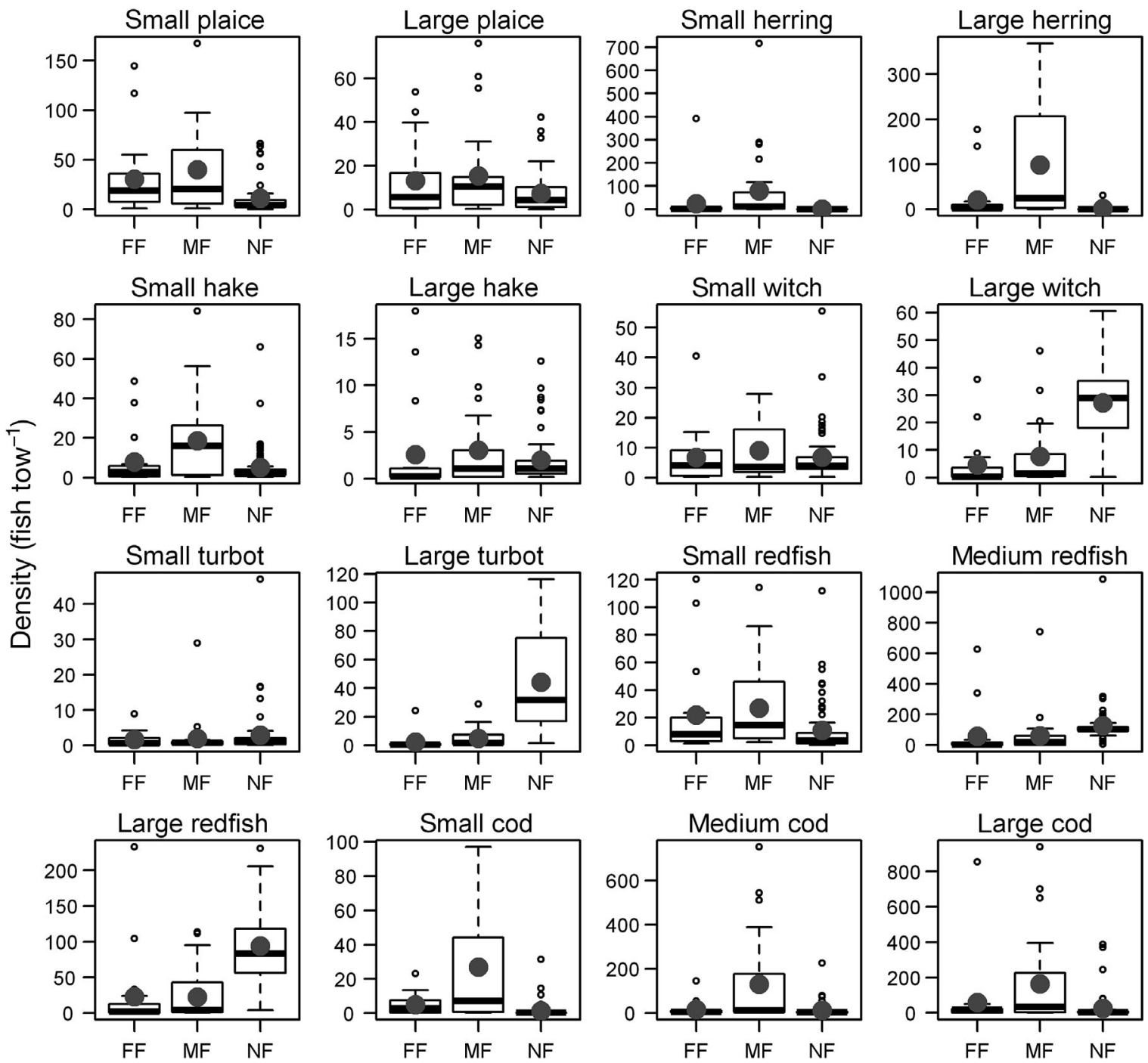

Fig. 4. Fish density distributions by species and size class (see Table 1) in female foraging zones (FF), male foraging zones $(\mathrm{MF})$, and randomly placed non-foraging zones (NF); Heavy lines: median; large grey circles: mean; boxes: interquartile range (IQR); whiskers: most extreme data points $\leq 1.5 \times$ IQR from the box; small open circles: more extreme data points 


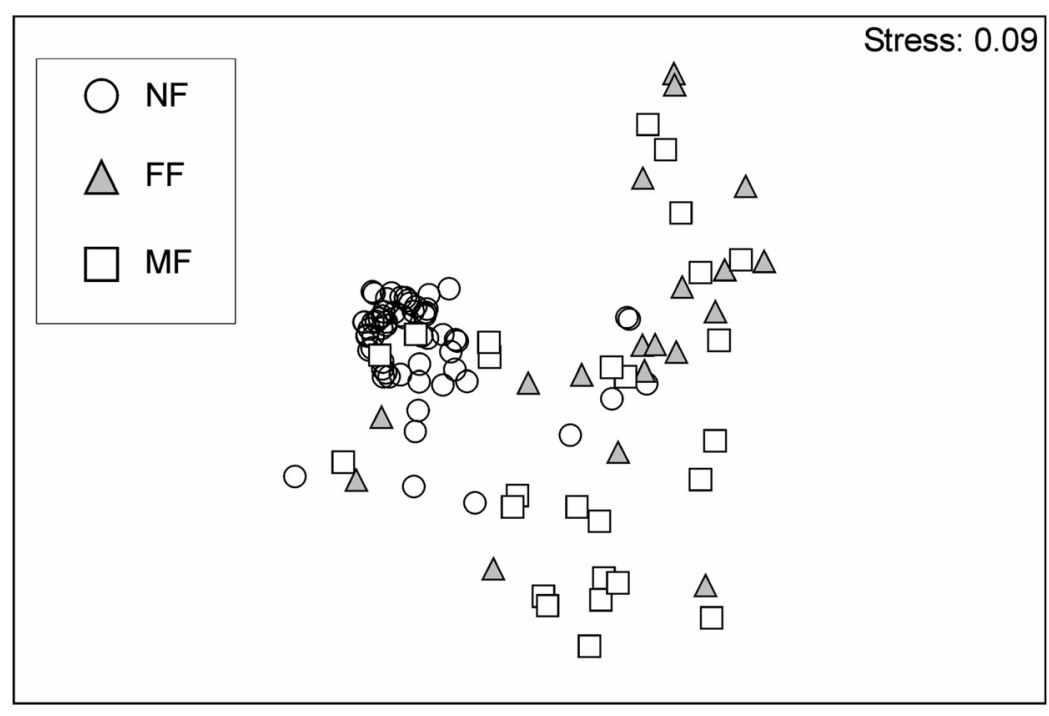

Fig. 5. MDS ordination of male foraging zones (MF), female foraging (FF) zones and randomly placed non-foraging zones (NF), based on the species and size composition of their fish communities. Stress is a measure of the distortion in rank similarity resulting from the 2-dimensional ordination (values $<0.1$ are considered to indicate a good representation of the similarities between samples)

Table 2. Main fish groups contributing to the similarity between zones within a zone type (male foraging zones, female foraging zones or randomly placed non-foraging zones). $\bar{C}$ is the average catch rate in a zone type, $\bar{S}$ is the average Bray-Curtis similarity between pairs of zones within a zone type, $\bar{S}_{i}$ is the contribution of fish group $i$ to similarity within a zone type averaged over all pairs of zones in the type, \%S is the percentage contribution to $\bar{S}$, and $\mathrm{SD}_{i}$ is the standard deviation of $S_{i}$. A high value for $\bar{S}_{i} / \mathrm{SD}_{i}$ indicates that fish group is typical for a given zone type (i.e. is found at consistently high abundance throughout the zone type)

\begin{tabular}{|lccccc|}
\hline Fish group & $\bar{C}$ & $\bar{S}_{i}$ & $\bar{S}_{i} / \mathrm{SD}_{i}$ & $\% S$ & Cumulative $\% S$ \\
\hline Non-foraging zones, $\bar{S}=59.77$ & & & & \\
Redfish $20-30 \mathrm{~cm}$ & 126.49 & 23.07 & 1.96 & 38.59 & 38.59 \\
Redfish $>30 \mathrm{~cm}$ & 93.92 & 17.04 & 2.01 & 28.50 & 67.10 \\
Turbot $\geq 35 \mathrm{~cm}$ & 44.11 & 7.61 & 1.28 & 12.72 & 79.82 \\
Witch flounder $\geq 30 \mathrm{~cm}$ & 27.23 & 5.43 & 1.75 & 9.08 & 88.90 \\
Male foraging zones, $\bar{S}=26.10$ & & & & \\
Cod $>35 \mathrm{~cm}$ & 163.94 & 4.15 & 0.63 & 15.89 & 15.89 \\
Herring $\geq 30 \mathrm{~cm}$ & 98.34 & 3.40 & 0.64 & 13.04 & 28.92 \\
Plaice $<30 \mathrm{~cm}$ & 39.74 & 3.26 & 0.82 & 12.51 & 41.43 \\
Cod $25-35 \mathrm{~cm}$ & 130.50 & 3.08 & 0.59 & 11.79 & 53.22 \\
Redfish $<20 \mathrm{~cm}$ & 26.98 & 2.09 & 0.81 & 8.02 & 61.24 \\
Herring $<30 \mathrm{~cm}$ & 60.34 & 1.84 & 0.52 & 7.04 & 68.28 \\
& & & & & \\
Female foraging zones,, $\bar{S}=26.25$ & & & & \\
Plaice $<30 \mathrm{~cm}$ & 30.47 & 7.27 & 0.92 & 27.69 & 27.69 \\
Redfish $<20 \mathrm{~cm}$ & 21.93 & 3.73 & 1.00 & 14.22 & 41.91 \\
Cod $>35 \mathrm{~cm}$ & 58.91 & 2.47 & 0.69 & 9.43 & 51.33 \\
Plaice $\geq 30 \mathrm{~cm}$ & 13.25 & 2.04 & 0.69 & 7.79 & 59.12 \\
Cod $25-35 \mathrm{~cm}$ & 15.64 & 1.58 & 0.99 & 6.02 & 65.14 \\
Cod $<25 \mathrm{~cm}$ & 4.98 & 1.34 & 0.48 & 5.11 & 70.25 \\
\hline
\end{tabular}

The main fishes (in order of importance) for each of the zones were medium and large redfish and large turbot and witch flounder for the nonforaging zones, small plaice and redfish and large cod for the female foraging zones, and large cod, large herring, small plaice and mediumsized cod for the male foraging zones (Table 2). The main fishes contributing to the average dissimilarity between the non-foraging and female foraging zones were medium and large redfish and large turbot, with all 3 fish groups at higher density in the non-foraging zones (Table 3). The non-foraging and male foraging zones were distinguished by relatively high densities of medium and large cod in the male foraging zones and relatively high densities of medium and large redfish in the non-foraging zones. Male foraging zones were distinguished from female foraging zones by higher densities of medium and large cod and both size classes of herring (Table 3).

\section{DISCUSSION}

During November and early December, most of the commercially important groundfish in the Gulf of the St Lawrence migrate to overwinter in the Laurentian Channel (Clay 1991, Darbyson \& Benoît 2003). Southern Gulf cod overwinter along the southern slope of the channel, in particular off St. Paul Island, while northern Gulf cod overwinter along the northern slope of the channel, in particular off the Burgeo Bank area (Swain et al. 2001). Many of these fishes, particularly cod, are highly aggregated in winter. Larger fish tend to be associated with deeper water further down the slope of the channel (Swain et al. 1998). This seasonal shift in the Gulf fish community coincides with a shift in distribution of grey seals as animals leave the estuary and northern Gulf and move into the southern Gulf or 
Table 3. Main fish groups contributing to the dissimilarity between zones in different zone types (male foraging zones, female foraging zones or randomly placed non-foraging zones). $\bar{C}_{1}$ is the average catch rate in zone type $1, \bar{\delta}$ is the average BrayCurtis dissimilarity between pairs of zones in different zone types, $\bar{\delta}_{i}$ is the contribution of fish group $i$ to the dissimilarity between zone types, $\% \delta$ is the percent contribution to $\% \delta$, and $\mathrm{SD}_{i}$ is the standard deviation of $\bar{\delta}_{i}$. A high value for $\delta_{i} / \mathrm{SD}_{i}$ indicates that fish group is a good discriminating variable among groups and among zone types

\begin{tabular}{|c|c|c|c|c|c|c|}
\hline Fish group & $\bar{C}_{1}$ & $\bar{C}_{2}$ & $\bar{\delta}_{\mathrm{i}}$ & $\bar{\delta}_{i} / \mathrm{SD}_{i}$ & $\% \delta$ & Cumulative $\% \delta$ \\
\hline \multicolumn{7}{|c|}{ Non-foraging zones (Type 1) versus male foraging zones (Type 2), $\bar{\delta}=78.21$} \\
\hline Redfish $20-20 \mathrm{~cm}$ & 126.49 & 60.34 & 14.82 & 1.07 & 18.95 & 18.95 \\
\hline $\mathrm{Cod}>35 \mathrm{~cm}$ & 25.09 & 163.94 & 10.60 & 0.95 & 13.55 & 32.50 \\
\hline Redfish $>30 \mathrm{~cm}$ & 93.92 & 22.32 & 10.57 & 1.15 & 13.51 & 46.01 \\
\hline Cod $25-35 \mathrm{~cm}$ & 12.60 & 130.50 & 7.86 & 0.88 & 10.05 & 56.07 \\
\hline Herring $\geq 30 \mathrm{~cm}$ & 1.18 & 98.34 & 6.86 & 0.93 & 8.77 & 64.84 \\
\hline Turbot $\geq 35 \mathrm{~cm}$ & 44.11 & 4.82 & 5.70 & 0.94 & 7.29 & 72.13 \\
\hline Herring $<30 \mathrm{~cm}$ & 0.16 & 78.14 & 5.41 & 0.58 & 6.92 & 79.05 \\
\hline \multicolumn{7}{|c|}{ Non-foraging zones (Type 1) versus female foraging zones (Type 2), $\bar{\delta}=81.56$} \\
\hline Redfish $20-20 \mathrm{~cm}$ & 126.49 & 56.55 & 22.97 & 1.75 & 28.16 & 28.16 \\
\hline Redfish $>30 \mathrm{~cm}$ & 93.92 & 23.16 & 16.09 & 1.63 & 19.73 & 47.89 \\
\hline Turbot $\geq 35 \mathrm{~cm}$ & 44.11 & 2.26 & 8.46 & 1.18 & 10.37 & 58.27 \\
\hline Cod $>35 \mathrm{~cm}$ & 25.09 & 58.91 & 6.89 & 0.53 & 8.44 & 66.71 \\
\hline Plaice $<30 \mathrm{~cm}$ & 10.99 & 30.47 & 4.79 & 0.87 & 5.87 & 72.58 \\
\hline Witch flounder $\geq 30 \mathrm{~cm}$ & 27.23 & 4.61 & 4.74 & 1.46 & 5.81 & 78.39 \\
\hline \multicolumn{7}{|c|}{ Female foraging zones (Type 1) versus male foraging zones (Type 2), $\bar{\delta}=76.64$} \\
\hline $\mathrm{Cod}>35 \mathrm{~cm}$ & 58.91 & 163.94 & 13.73 & 0.96 & 17.91 & 17.91 \\
\hline Redfish $20-30 \mathrm{~cm}$ & 56.55 & 60.34 & 9.91 & 0.62 & 12.93 & 30.84 \\
\hline Herring $\geq 30 \mathrm{~cm}$ & 20.48 & 98.34 & 9.24 & 0.99 & 12.06 & 42.90 \\
\hline Cod $25-35 \mathrm{~cm}$ & 15.64 & 130.50 & 9.10 & 0.94 & 11.87 & 54.77 \\
\hline Herring $<30 \mathrm{~cm}$ & 24.11 & 78.14 & 7.72 & 0.67 & 10.07 & 64.84 \\
\hline Plaice $<30 \mathrm{~cm}$ & 30.47 & 39.74 & 5.66 & 0.95 & 7.39 & 72.23 \\
\hline Redfish $>30 \mathrm{~cm}$ & 23.16 & 22.32 & 4.72 & 0.69 & 6.16 & 78.39 \\
\hline
\end{tabular}

onto the Scotian Shelf (mean date $=25$ November) (Harvey et al. 2008).

In the present study, location information from free-ranging grey seals equipped with satellite transmitters and winter bottom-trawl survey data were combined to quantify the degree of overlap between grey seals and overwintering fish species of commercial interest in the Cabot Strait/northeast Cape Breton area. Our results suggest considerable overlap between male grey seal foraging zones and the areas occupied by overwintering cod and herring in the Cabot Strait area, particularly during early winter (December to January).

Grey seals are generally strongly associated with shallow waters (Harvey et al. 2008). They are also central place foragers (McConnell et al. 1999, Austin et al. 2004). The necessity to alternate hauling-out with foraging trips undoubtedly limits the searching range of seals to some degree. Within the study area, grey seal foraging zones were concentrated in shelf and slope areas on the south side of the channel, particularly around St. Paul Island and on the Scotian Shelf in the southern part of NAFO fishing zone $4 \mathrm{Vn}$ (Fig. 1). The proximity to haul-out sites on St. Paul Is- land allows grey seals to forage on the dense aggregations of prey overwintering in this vicinity, even though in this area, the fish, in particular medium and large cod, occur in relatively deep water.

The fish communities differed significantly between foraging and non-foraging zones of grey seals. The composition of the fish community was very similar throughout the non-foraging zones. Few grey seals foraged on the banks in the northern part of the study area or in the deep waters of the Laurentian Channel, the areas where redfish (particularly those $>20 \mathrm{~cm}$ in length), witch flounder and turbot were distributed. Foraging zones were distinguished from non-foraging zones by the absence of deepwater fish groups and by high densities of medium and large cod and large herring (male seals) or by higher densities of large cod and small plaice (female seals). Such sex differences in diet as well as foraging strategy and blubber accumulation have been reported elsewhere (Beck et al. 2005, 2007, Breed et al. 2006) and likely reflect different reproductive strategies of the 2 sexes.

The fish species selected for this analysis composed the majority of the total catch in the January surveys 
( $59 \%$ by number and $77 \%$ by weight). Much of the remaining catch $(22 \%$ by number and $13 \%$ by weight) consisted of 3 species: black dogfish Centroscyllium fabricii, common grenadier Nezumia bairdi and longfin hake Phycis chesteri. These 3 species are confined to the deep waters of the Laurentian Channel, an area rarely used by foraging grey seals in our study. Capelin Mallotus villosus also made an important contribution to the total catch in the surveys ( $11 \%$ by number, $0.4 \%$ by weight), and large catches of capelin did occur on the Scotian Shelf in the southern part of the study area, where female foraging zones were frequently situated. However, these large catches were restricted to 1995, and catches of capelin in the other 3 survey years were small. Sandlance Ammodytes spp., an important prey species for grey seals in some areas and seasons, were very rare in the January survey catches $(0.04 \%$ by number and $0.001 \%$ by weight). The trawls used in the January survey will catch sandlance when they are abundant, so this suggests that sandlance are not an abundant fish in our study area. This is confirmed by the annual July survey of the Scotian Shelf, in which large numbers of sandlance are caught on the banks but very little within our study area, except for in the southernmost areas (see Fig. A2 in the Appendix).

Our analysis compared the winter (December to April, 1993 to 2005) movements of seals with the distribution of fish surveyed from January 1994 to 1997. Too few transmitters were deployed on seals in the early years of the study to allow us to limit our analyses of seal movements to only the 1994 to 1997 period, and limited financial resources have precluded conducting additional winter fish surveys. Thus, our analysis assumes that the average distribution of fish in January 1994 to 1997 is representative for winters over the whole 1993 to 2005 period. Depth plays a dominant role in determining the species composition of demersal fish assemblages (e.g. Bianchi 1992, Tolimieri \& Levin 2006), and it is likely that the depth-dependent patterns in fish distribution characterized by the average 1994 to 1997 distributions are conserved throughout the study period. This is supported by the similar distributions between years in the 1994 to 1997 timeframe (Chouinard \& Hurlbut 2011). In particular, a dense aggregation of large cod was observed off St. Paul Island in all 4 years surveyed. Although the abundance of southern Gulf cod has declined further, by $58 \%$ between 1995 and 2009 (DFO 2009), the winter aggregation of large cod off St. Paul Island appears to have persisted. A very large cod aggregation was detected in this area in January 2001 (Comeau et al.
2002). The limited commercial fishing that continued up to 2008 was concentrated in the St. Paul Island area in December and January (Swain et al. 2009). However, we cannot say with certainty that there were no changes in fish distributions over the study period. We know that ice coverage does influence movement patterns. When ice extends into the Cabot Strait later in winter, southern Gulf cod may extend their distribution further south along the slope of the channel. This may partly explain the difference in the distribution of foraging zones between early and late winter.

The FPT method provides an unbiased approach to defining putative foraging areas, although some authors have criticized this approach (e.g. Barraquand \& Benhamou 2008) for the lack of biological meaning in the definition of the radius of the foraging areas. Nonetheless, FPT allowed us to define standard zones scaled to the movement patterns of the seals, in which we could compare fish abundance and community composition between areas used by seals and areas not used by seals. These comparisons identified considerable overlap between aggregations of large cod in the St. Paul Island area and male grey seals from the Gulf. However, we also observed that fewer seals established ARS in this region after the year 2000. This is likely due to a greater proportion of the post-2000 deployments consisting of Sable Island animals, which were less likely to use the St. Paul Island area than Gulf animals, but we cannot exclude the possibility of some functional response to the overall decline in cod abundance or that this change in seal distribution might reflect a shift in fish distribution.

Grey seals are primarily piscivorous, with invertebrates accounting for only a small fraction of their diet (Bowen et al. 1993, Hammill et al. 2007). Both spatial and temporal differences in diet have been reported, but usually $<8$ species account for $\sim 80 \%$ of the diet, with individual seals often specializing in even fewer prey species (Bowen et al. 2006, Hammill et al. 2007, Tucker et al. 2008). Small herring, hake and medium-sized cod are among the species most commonly observed in diets of grey seals from the Gulf of St. Lawrence (Benoît \& Bowen 1990, Murie \& Lavigne 1992, Hammill \& Stenson 2000, Hammill et al. 2007), while sandlance, redfishes, flatfishes, cod and witch flounder are important grey seal prey on the Scotian Shelf (Bowen \& Harrison 1994, Bowen et al. 2006, Beck et al. 2007).

Natural mortality is currently elevated among large southern Gulf cod, and despite very low levels of fishing mortality, this stock continues to decline (Swain \& 
Chouinard 2008). Predation by grey seals has been proposed as one factor in the failure of this stock to recover (Chouinard et al. 2005). Overlap between aggregations of large cod and foraging grey seals, particularly in the St. Paul Island area of the Cabot Strait, provides support for this hypothesis. However, cooccurrence does not necessarily indicate predation. Co-occurrence also cannot be used to determine whether cod and seals are feeding on the same prey because cod feed very infrequently on the overwintering grounds (Schwalme \& Chouinard 1999). To determine whether grey seals are targeting the large cod aggregated near St. Paul Island or some other prey that co-occur with cod at this time, grey seal diet samples are needed. Additional winter surveys would also confirm whether winter aggregations of cod in this area have persisted in spite of continued decline in cod biomass.

Acknowledgements. We thank field crews in the Gulf and on Sable Island for assistance in the capture and deployment of satellite transmitters as well as members of the winter groundfish missions for collecting the fish survey data. We thank W. Bowen (DFO-Dartmouth) for allowing us to use the Sable Island satellite transmitter data. We are also grateful to S. Hamel and A. Masse for their help with statistical analyses and to G. Chouinard, H. Benoît and N. den Heyer for discussion and comments on this work. This work was supported by the Department of Fisheries and Oceans Canada (Atlantic Seal Research Program) and the DFO Centre of Expertise on Marine Mammalogy.

\section{LITERATURE CITED}

Austin D, Bowen WD, McMillan JI (2004) Intraspecific variation in movement patterns: modeling individual behaviour in a large marine predator. Oikos 105:15-30

Barraquand F, Benhamou S (2008) Animal movements in heterogeneous landscapes: identifying profitable places and homogenous movement bouts. Ecology 89:3336-3348

Beck CA, Iverson SJ, Bowen WD (2005) Blubber fatty acids of gray seals reveal sex differences in the diet of a sizedimorphic marine carnivore. Can J Zool 83:377-388

Beck CA, Iverson SJ, Bowen WD, Blanchard W (2007) Sex differences in grey seal diet reflect seasonal variation in foraging behaviour and reproductive expenditure: evidence from quantitative fatty acid signature analysis. J Anim Ecol 76:490-502

Benoît D, Bowen WD (1990) Seasonal and geographic variation in the diet of grey seals (Halichoerus grypus) in eastern Canada. Can J Fish Aquat Sci 222:215-226

> Benoît HP, Swain DP (2008) Impacts of environmental change and direct and indirect harvesting effects on the dynamics of a marine fish community. Can J Fish Aquat Sci 65:2088-2104

Benoît HP, Swain DP, Bowen WD, Breed GA, Hammill MO, Harvey V (2011) Evaluating the potential for grey seal predation to explain elevated natural mortality in three fish species in the southern Gulf of St. Lawrence. Mar Ecol Prog Ser 442:149-167
Bernt KE, Hammill MO, Kovacks KM (1996) Age estimation of grey seals (Halichoerus grypus) using incisors. Mar Mamm Sci 12:476-482

Bianchi G (1992) Demersal assemblages of the continental shelf and upper slope of Angola. Mar Ecol Prog Ser 81: 101-120

Bowen WD, Harrison GD (1994) Offshore diet of grey seals Halichoerus grypus near Sable Island, Canada. Mar Ecol Prog Ser 112:1-11

> Bowen WD, Lawson JW, Beck B (1993) Seasonal and geographic variation in the species composition and size of prey consumed by grey seals (Halichoerus grypus) on the Scotian shelf. Can J Fish Aquat Sci 50:1768-1778

Bowen WD, Beck CA, Iverson SJ, Austin D, McMillan JI (2006) Linking predator foraging behaviour and diet with variability in continental shelf ecosystems: grey seals of eastern Canada. In: Boyd I, Wanless S, Camphuysen CJ (eds) Top predators in marine ecosystems: their role in monitoring and management. Cambridge University Press, Cambridge, p 63-81

Breed GA, Bowen WD, McMillan JI, Leonard ML (2006) Sexual segregation of seasonal foraging habitats in a non-migratory marine mammal. Proc R Soc Lond B Biol Sci 273:2319-2326

Breed GA, Jonsen ID, Myers RA, Bowen WD, Leonard ML (2009) Sex-specific, seasonal foraging tactics of adult grey seals (Halichoerus grypus) revealed by state-space analysis. Ecology 90:3209-3221

Burnham KP, Anderson DR (2002) Model selection and multimodel inference: a practical information-theoretic approach. Springer, New York, NY

Canadian Council on Animal Care (1993) Guide to the care and use of experimental animals. Bradda Printing Services, Ottawa

Chouinard GA, Hurlbut TR (2011) An atlas of the January distribution of selected marine fish species in the Cabot Strait from 1994 to 1997. Can Tech Rep Fish Aquat Sci 2967, Fisheries and Oceans Canada, Ottawa

Chouinard GA, Swain DP, Hammill MO, Poirier GA (2005) Covariation between grey seal (Halichoerus grypus) abundance and natural mortality of cod (Gadus morhua) in the southern Gulf of St. Lawrence. Can J Fish Aquat Sci 62:1991-2000

Clarke KR, Gorley RN (2001) PRIMER v5: user manual/tutorial. PRIMER-E, Plymouth

Clarke KR, Green RH (1988) Statistical design and analysis for a 'biological effects' study. Mar Ecol Prog Ser 46: 213-226

Clay D (1991) Seasonal distribution of demersal fish (Osteichthyes) and skates (Chondrichthyes) in the southeastern Gulf of St. Lawrence. Publ Spec Can Sci Halieut Aquat 113:241-259

> Comeau LA, Campana SE, Castonguay M (2002) Automated monitoring of a large-scale cod (Gadus morhua) migration in the open sea. Can J Fish Aquat Sci 59:1845-1850

Darbyson E, Benoît HP (2003) An atlas of the seasonal distribution of marine fish and invertebrates in the southern Gulf of St. Lawrence. Can Data Rep Fish Aquat Sci 1113, Fisheries and Oceans Canada, Ottawa

DFO (2009) Assessment of cod in the southern Gulf of St. Lawrence. DFO Can Sci Advis Sec Sci Advis Rep 2009/ 007, Fisheries and Oceans Canada, Ottawa

> Fauchald P, Tveraa T (2003) Using first-passage time in the analysis of area-restricted search and habitat selection. Ecology 84:282-288 
Freitas C, Kovacs KM, Ims RA, Fedak MA, Lydersen C (2008) Ringed seal post-moulting movement tactics and habitat selection. Oecologia 155:193-204

Hammill MO, Stenson GB (2000) Estimated prey consumption by harp seals (Phoca groenlandica), hooded seals (Cystophora cristata), grey seals (Halichoerus grypus) and harbour seals (Phoca vitulina) in Atlantic Canada. J Northwest Atl Fish Sci 26:1-23

Hammill MO, Stenson GB, Proust F, Carter P, McKinnon D (2007) Feeding by grey seals in the Gulf of St. Lawrence and around Newfoundland. In: Haug T, Hammill M, Olafsdottir D (eds) Grey seals in the North Atlantic and the Baltic. NAMMCO Sci Publ 6, Tromsø, p 135-152

Harvey V, Côté SD, Hammill MO (2008) The ecology of 3-D space use in a sexually dimorphic mammal. Ecography 31:371-380

> Hauser DDW, Allen CS, Rich HB Jr, Quinn TP (2008) Resident harbor seals (Phoca vitulina) in Iliamna Lake, Alaska: summer diet and partial consumption of adult sockeye salmon (Oncorhynchus nerka). Aquat Mamm 34:303-309

> Johnson DH (1980) The comparison of usage and availability measurements for evaluating resource preference. Ecology 61:65-71

Lavigueur L, Hammill MO (1993) Distribution and seasonal movements of grey seals, Halichoerus grypus, born in the Gulf of St. Lawrence and eastern Nova Scotia shore. Can Field Nat 107:329-340

Lemieux-Lefebvre S (2009) Déplacements et patrons de résidence chez la population de bélugas (Delphinapterus leucas) de l'estuaire du St-Laurent. MSc thesis, Université du Québec à Rimouski

Manly BFJ, McDonald LL, Thomas DL, McDonald TL, Erickson WP (2002) Resource selection by animals: statistical design and analysis for field studies. Kluwer Academic, Dordrecht

McConnell BJ, Fedak MA, Lovell P, Hammond PS (1999) Movements and foraging areas of grey seals in the North Sea. J Appl Ecol 36:573-590

Morissette L, Hammill MO, Savenkoff C (2006) The trophic role of marine mammals in the northern Gulf of St. Lawrence. Mar Mamm Sci 22:74-103

Murie DJ, Lavigne DM (1992) Growth and feeding habits of grey seals (Halichoerus grypus) in the northwestern Gulf of St. Lawrence, Canada. Can J Fish Aquat Sci 70: 1604-1613

Phillips EM, Harvey JT (2009) A captive feeding study with the Pacific harbor seal (Phoca vitulina richardii): implications for scat analysis. Mar Mamm Sci 25:373-391

Pinaud D (2008) Quantifying search effort of moving animals at several spatial scales using first-passage time analysis: effect of the structure of environment and tracking systems. J Appl Ecol 45:91-99

Rivoirard J, Simmonds J, Foote KG, Fernandes P, Bez N (2000) Geostatistics for estimating fish abundance. Blackwell Science, Oxford

Savenkoff C, Swain DP, Hanson JM, Castonguay M and others (2007) Effects of fishing and predation in a heavily exploited ecosystem: comparing periods before and after the collapse of groundfish in the southern Gulf of St. Lawrence (Canada). Ecol Model 204:115-128

Schwalme K, Chouinard GA (1999) Seasonal dynamics in feeding, organ weights, and reproductive maturation of Atlantic cod (Gadus morhua L.) in the southern Gulf of St. Lawrence. ICES J Mar Sci 56:303-319

Swain DP, Chouinard GA (2008) Predicted extirpation of the dominant demersal fish in a large marine ecosystem: Atlantic cod (Gadus morhua) in the southern Gulf of St. Lawrence. Can J Fish Aquat Sci 65:2315-2319

Swain DP, Chouinard GA, Morin R, Drinkwater KF (1998) Seasonal variation in the habitat associations of Atlantic cod (Gadus morhua) and American plaice (Hippoglossoides platessoides) from the southern Gulf of St. Lawrence. Can J Fish Aquat Sci 55:2548-2561

Swain DP, Frank KT, Maillet G (2001) Delineating stocks of Atlantic cod (Gadus morhua) in the Gulf of St. Lawrence and Cabot Strait areas using vertebral number. ICES J Mar Sci 58:253-269

Swain DP, Savoie L, Hurlbut T, Surette T, Daigle D (2009) Assessment of the southern Gulf of St. Lawrence cod stock, February 2009. DFO Can Sci Advis Sec Res Doc 2009/037, Fisheries and Oceans Canada, Ottawa

Thomas L, Hammill MO, Bowen WD (2008) Assessment of population consequences of harvest strategies for the Northwest Atlantic grey seal population. DFO Can Sci Advis Sec Res Doc 2008/78, Fisheries and Oceans Canada, Ottawa

Tolimieri N, Levin PS (2006) Assemblage structure of eastern Pacific groundfishes on the U.S. continental slope in relation to physical and environmental variables. Trans Am Fish Soc 135:317-332

> Tucker S, Bowen WD, Iverson SJ (2008) Convergence of diet estimates derived from fatty acids and stable isotopes within individual grey seals. Mar Ecol Prog Ser 354: $267-276$

> Weimerskirch H, Pinaud D, Pawlowski F, Bost CA (2007) Does prey capture induce area-restricted search? A finescale study using GPS in a marine predator, the wandering albatross. Am Nat 170:734-743

Yodzis P (1998) Local trophodynamics and the interaction of marine mammals and fisheries in the Benguela ecosystem. J Anim Ecol 67:635-658 
Appendix 1. Additional data representing fish distribution, supporting the results of the present study: annual distribution of cod in January in Cabot Strait and distribution of northern sandlance on the eastern Scotian Shelf according to July fish surveys

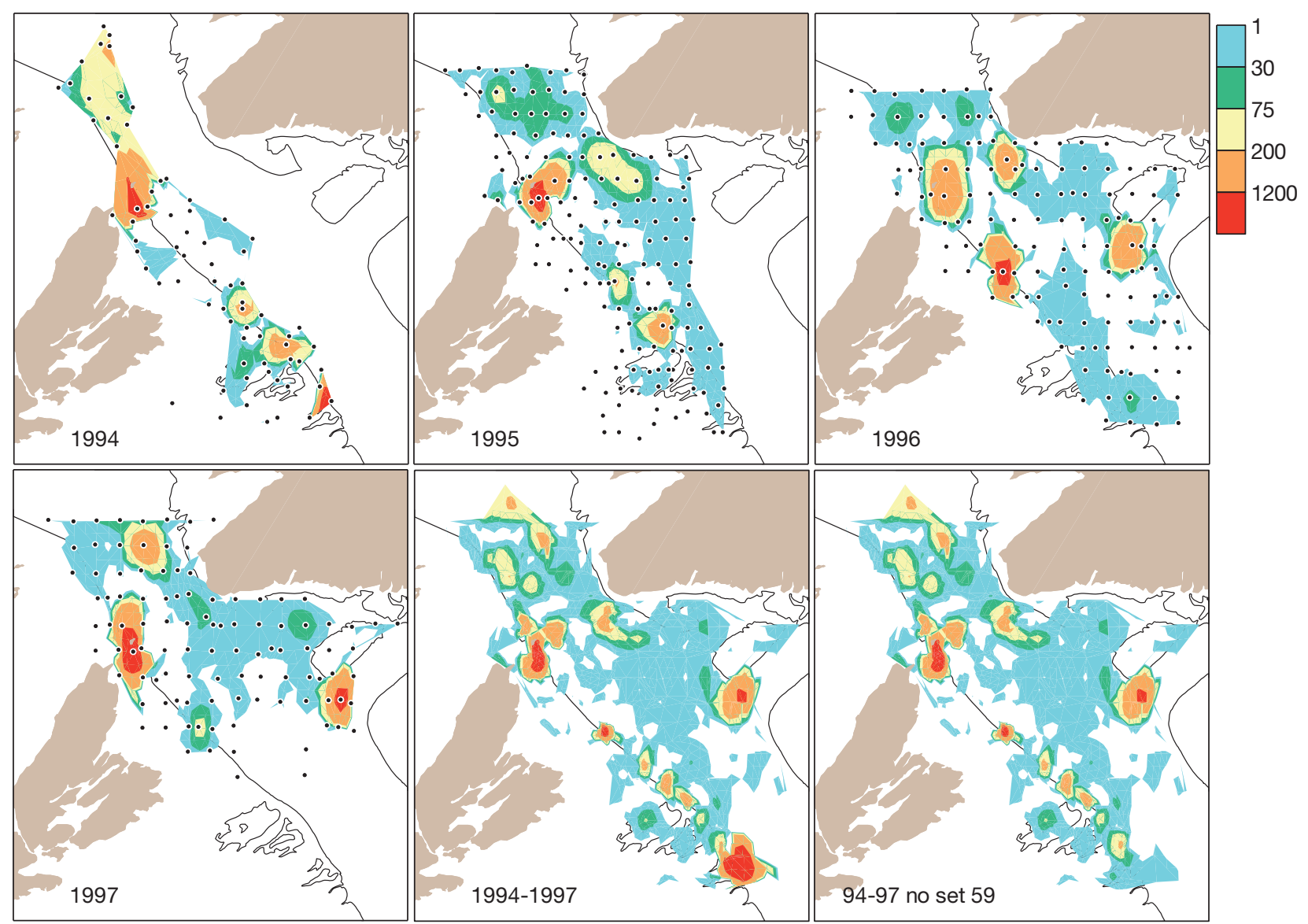

Fig. A1. Distribution (mean number per tow) of cod $>35 \mathrm{~cm}$ in length in January surveys of the Cabot Strait. Thin lines: $200 \mathrm{~m}$ depth contour

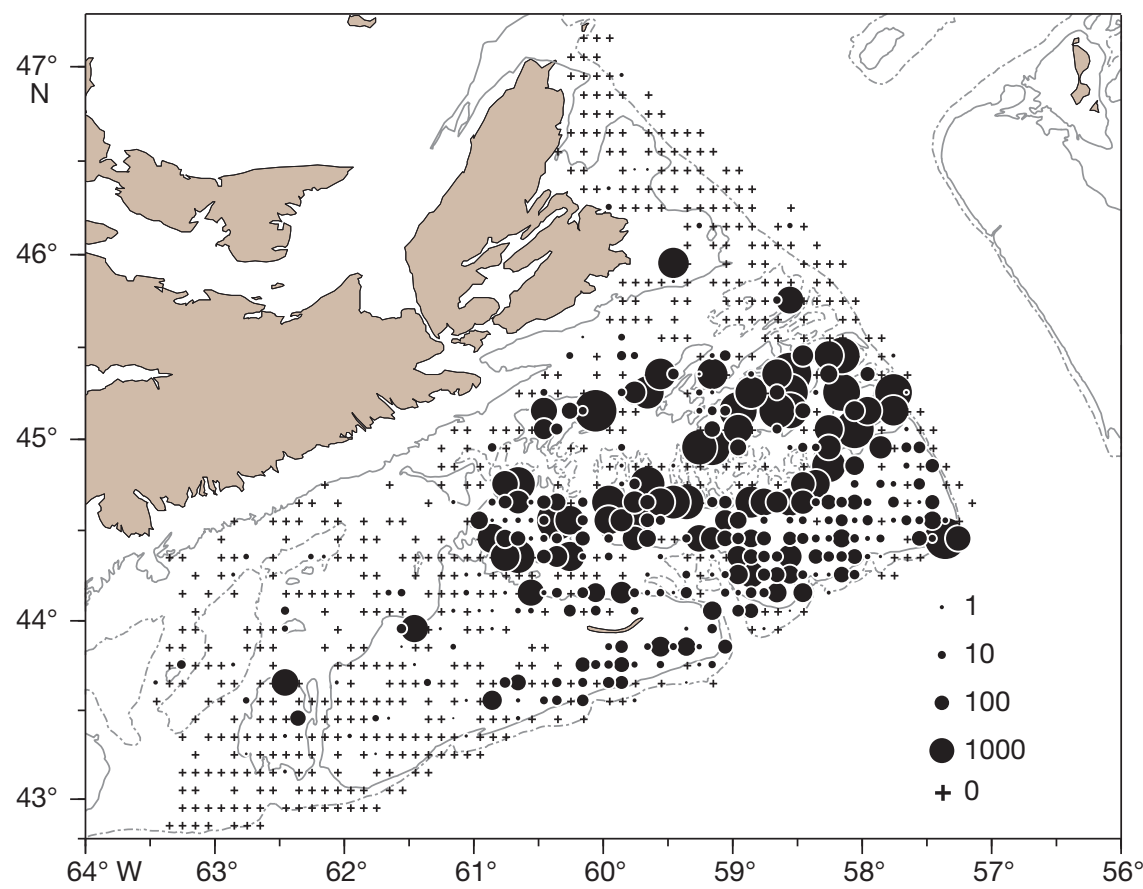

Fig. A2. Distribution of northern sandlance in July surveys of the eastern Scotian Shelf, 1998 to 2011. Circle size is proportional to catch rate (average number of fish per tow), with tows aggregated into $0.1 \times 0.1^{\circ}$ cells. Crosses indicate cells with tows but no sandlance caught. Grey lines are the 100 (solid line) and $200 \mathrm{~m}$ (dashed line) depth contours 